\title{
Reactivation of Chagas' Disease Leading to the Diagnosis of Acquired Immunodeficiency Syndrome
}

Eder de Oliveira Santos, João dos Reis Canela, Henry Carlos Gomes Monção and Mauro José Guedes Roque
Universitary Hospital Clemente Faria, State University of Montes Claros, Minas Gerais, Brazil

\begin{abstract}
Reactivation of chronic Chagas' disease is a rare condition and occurs only in immunosuppressed patients. We report a case of a patient with a rapid and fatal reactivation of Chagas' disease, manifested by meningoencephalitis, which lead to a diagnosis of acquired immunodeficiency syndrome (AIDS). We believe there is sufficient evidence to include the reactivation of Chagas' disease among the diagnostic criteria of AIDS in Human Immunodeficiency Virus (HIV) infection.

Key Words: Chagas' disease, Trypanosoma cruzi, acquired immunodeficiency syndrome, human immunodeficiency virus, meningoencephalitis.
\end{abstract}

Chagas' disease (American Trypanosomiasis) is caused by Trypanosoma cruzi and is endemic throughout most of Latin America. The progressive spread of Human Immunodeficiency Virus (HIV) towards smaller communities and the countryside has reached endemic areas of Chagas' disease, modifying the natural history of this latter disease [1].

We report a case of a 26-year-old male patient with a rapid and fatal reactivation of a known chronic case of Chagas' disease, manifested by meningoencephalitis, which lead to a diagnosis of acquired immunodeficiency syndrome(AIDS).

\section{Case Report}

A 26-year-old male patient from an area endemic for Chagas' disease in northern Minas Gerais state, southeastern Brazil, was admitted to the Hospital UniversitárioClemente Faria, a teaching hospital at the Universidade Estadual de

Received on 17 July 2002; revised 25 October 2002.

Address for correspondence: Dr. Eder de Oliveira Santos. Rua Pastor Raimundo Fernandes, 204. Bairro Santa Rita. Montes Claros - MG, Zip code: 39400-416. Phones: (38) 3221-1329, (38)9964-4177.E-mail: dr.eder@zipmail.com.br

The Brazilian Journal of Infectious Diseases 2002;6(6):317-321 (C) 2002 by The Brazilian Journal of Infectious Diseases and Contexto Publishing. All rights reserved. $1413-8670$
Montes Claros. He had been diagnosed as having Chagas' disease and heart failure eight months prior to admission. The patient had a history of chronic diarrhea, progressive dyspnea and loss of approximately $20 \mathrm{~kg}$ in eight months. Seven days prior to admission, he began a progressive decrease in consciousness.

On physical examination, the patient was stuporous, dehydrated, cachectic, and had a temperature of $36.3^{\circ} \mathrm{C}$, a pulse rate of 100 beats/minute, and his blood pressure was $140 / 70 \mathrm{mmHg}$. Nolymphadenopathy was found. Heart auscultation exhibited a third sound and few premature beats. Lung auscultation revealed discrete crackles around the thorax. On abdominal examination, the edge of the liver was $3 \mathrm{~cm}$ below the right costal margin. The spleen was not palpable.

The patient had a hematocrit of $28 \%$, a white blood cell count of $3,700 / \mathrm{mm}^{3}$ (33\% band forms, $62 \%$ neutrophils, $4 \%$ lymphocytes and $1 \%$ monocytes), a platelet count of $35,000 / \mathrm{mm}^{3}$, a creatinine of $1.7 \mathrm{mg} /$ $\mathrm{dl}$, and $100 \mathrm{mg} / \mathrm{dl}$ glucose. The total serum protein was $4.2 \mathrm{mg} / \mathrm{dl}$, with $1.3 \mathrm{mg} / \mathrm{dl}$ albumin, and $2.9 \mathrm{mg} / \mathrm{dl}$ globulin.

T. cruzi infection was confirmed by positive indirect hemagglutination assay and indirect immunofluorescence assay. Serological tests for toxoplasmosis and leishmaniasis were negative. The patient's suspicion of seropositivity for HIV infection was confirmed by ELISA and Western Blot analysis. 
Twenty-four hours after admission, the neurological picture worsened, with a decrease in consciousness. A lumbar puncture revealed cerebrospinal fluid (CSF) with 90 cells/ $\mathrm{mm}^{3}$ (100\% lymphocytes), a glucose level of $51 \mathrm{mg} / \mathrm{dl}$ and a protein level of $83 \mathrm{mg} / \mathrm{dl}$. Direct examination showed abundant free flagellated forms. A May-GrunwaldGiemsa-stained smear permitted the morphological characterization of trypomastigote forms of T. cruzi (Figure 1). A specific culture for T. cruzi was positive.

The patient worsened rapidly, and death occurred 36 hours after admission, with no specific therapeutic measure.

\section{Discussion}

Reactivation of chronic Chagas' disease is a rare condition and occurs only in immunosuppressed patients $[2,3]$, probably due to a rupture in the delicate balance between the parasite and the cellular immune system [4]. Patients at especially high risk are those submitted for transplants [5,6], those that have leukemia [2], lymphoma [7], and especially, AIDS [3,4,8-21].

High parasitemia and parasitism of the central nervous system (CNS) occurs in reactivated Chagas' disease in patients with AIDS, leading to meningoencephalitis and tumor-like cerebral lesions. Myocarditis may occur associated with the CNS picture, or rarely as the sole manifestation $[1,8,9,22]$. A literature review showed CNS disease in $75 \%$ and cardiac involvement in $44 \%$ of cases [10]. There is a report of a reactivation with a skin lesion [11] and another with spontaneous chagasic peritonitis [12].

Patients with chagasic meningoencephalitis and AIDS present a feverish syndrome, accompanied by headache, nausea, seizure and focal neurological signs. Acute myocarditis may be present [10,23,24].

Early diagnosis of Chagas' disease reactivation in HIV infected patients is fundamental for a good prognosis. But it is an enormous challenge, demanding a high index of suspicion, based on the clinical picture and epidemiological data $[13,23]$.

The high parasitemia can be seen by direct microscope examination of blood [22]. Sartori et al. [8] emphasized that appearance of the buffy coat on direct microscope examination characterizes reactivation of Chagas' disease in immunosuppressed patients.

Parasitism of CNS can be suggested with the detection of $T$. cruzi antibodies in the CSF, but definitive diagnosis is made by demonstration of free trypomastigote forms in the CSF $[2,5,14,15]$. Centrifugation of the CSFenhances the sensibility of the test [26].

Biochemical analysis of CSF has shown, in most cases that have been reported including the case related here, mild pleocytosis with a predominance of lymphocytes and raised protein levels and, in some cases, low glucose levels $[10,16,17,23,24]$.

A polymerase chain reaction (PCR) assay of the CSF is a promising test for early demonstration of the presence and elimination of T. cruzi [13], but more studies are necessary to determine the real efficiency of this test in the detection of reactivation of Chagas' disease in patients with HIV infection.

If $T$. cruzi cannot be demonstrated in the CSF, or lumbar puncture is contraindicated (for instance, in cases of an expanding mass with intracranial hypertension), a cerebral biopsy may be necessary.

Histopathological findings include an intense inflammatory infiltration with necrosis and hemorrhage. Amastigote forms of T. cruzi are found in glial cells, macrophages, interstitial tissue, and rarely in neurons [2,10,23,24,27]. Lazo et al. [27] propose the label of focal necrotizing chagasic meningoencephalitis for chagasic meningoencephalitis of HIV-positive patients, because of its similarity to focal necrotizing toxoplasmic encephalitis.

Computerized tomography and magnetic resonance show simple or multiple, unilateral or bilateral, hypodense lesions, with or without an image of a ring enhancing lesion after contrast injection. A mass effect may be present. [3,10,23,24,28,29]. The imaging may be indistinguishable from that of toxoplasmic encephalitis [8,14,23]. A useful feature to differentiate the etiology is the absence of lesions in basal ganglia in Chagas' disease, which is generally a common target in toxoplasmic encephalitis [3,10,29]. Other causes of cerebral mass in patients with AIDS should be considered in the differential diagnosis $[18,28]$.

Benznidazole and nifurtimox are both effective in 
Figure 1. Trypomastigote forms of Trypanosoma cruzi in cerebrospinal fluid (Grunwald-Giemsa-stained smear; original magnification $\mathrm{x} 1000$ ).

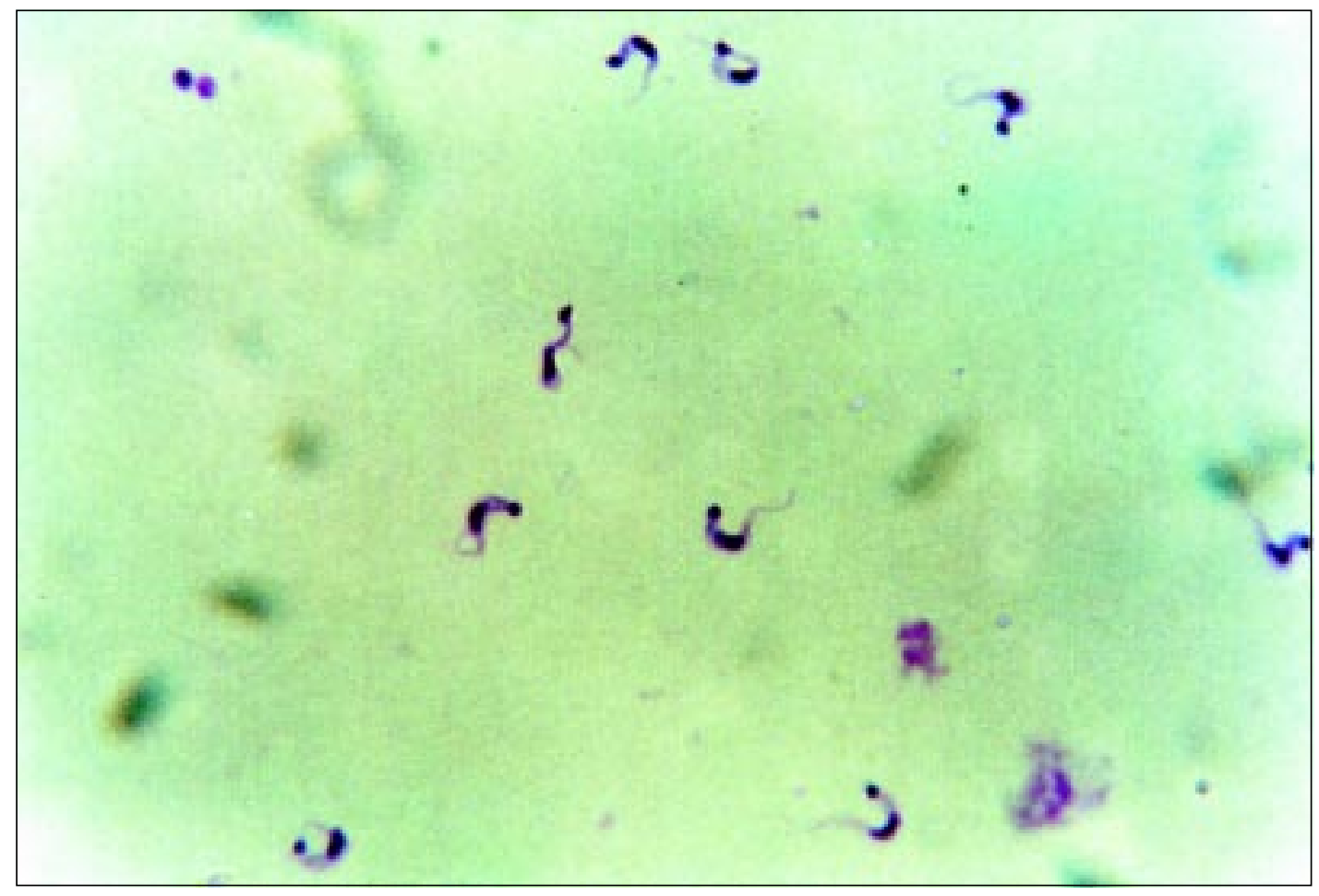

the treatment of Chagas' disease reactivation, when started early $[3,10,19,23,24]$. Some articles have reported clinical improvement with benznidazole plus subsequent itraconazole and fluconazole therapy, the latter with good penetration into the CNS [18,20].

The administration of corticoids should be delayed or avoided because of adverse effects on host responses to infection [19].

Primary prophylaxis with benznidazole or nifurtimox is controversial and more studies are necessary to determine if they really are beneficial, since these drugs have considerable side effects [10,30]. On the other hand, AIDS treatment with antiretroviral drugs improves cellular immunity and therefore reduces the possibility of disease reactivation [3,24]. Secondary prophylaxis with antitrypanosomal drugs should be pursued for those patients who respond to therapy $[3,10,23]$.

Chagasic meningoencephalitis has a bad prognosis when no specific treatment is initiated or when it is delayed [10,20,24]. A high index of suspiciousness is necessary for early diagnosis and treatment, whenever the patient presents involvement of the CNS, particularly in an area endemic for Chagas' disease [16,21].

In the case reported here, the suspicion and confirmation of HIV infection and AIDS occurred after the presentation of meningoencephalitis. Although other signs of immunodeficiency had already appeared, such as weight loss, chronic diarrhea and pancytopenia, the reason that the patient requested medical assistance was decreasing consciousness, caused by the intense parasitism of the CNS by T. cruzi. In two previous reports, chagasic meningoencephalitis was the first sign of AIDS [3,19]. We and other authors [3,9,21] believe there is sufficient evidence to include the reactivation of Chagas' disease among the diagnostic criteria of AIDS in HIV-infected patients.

\section{References}

1. Morgado M.G., Barcellos C., Pina M.F., Bastos F.I. Human immunodeficiency virus/acquired immunodeficiency syndrome and tropical diseases: a brazilian perspective. Mem Inst Oswaldo Cruz 2000;95: 145-51. 
2. Salgado P.R., Gorski A.G., Aleixo A.R., Barros E.O.M. Tumor-like lesion due to Chagas' disease in a patient with lymphocytic leukemia. Rev Inst Med Trop São Paulo 1996;38:285-8.

3. Pagano M.A., Segura M.J., Di Lorenzo G.A., et al. Cerebral tumor-like American trypanosomiasis in acquired immunodeficiency syndrome. Ann Neurol 1999;45:403-6.

4. Sartori A.M.C., Lopes M.H., Benvenuti L.A., et al. Reactivation of Chagas' disease in a human immunodeficiency virus-infected patient leading to severe heart disease with a late positive direct microscopic examination of the blood. Am J Trop Med Hyg 1998;59:784-6.

5. Jardim E., Takayanagui O.M. Chagasic meningoencephalitis with detection of Trypanosoma cruzi in the cerebrospinal fluid of an immunodepressed patient. Am J Trop Med Hyg 1994;97:367-70.

6. Amato J.G.P., Amato Neto V., Amato V.S., et al. Lesões cutâneas como únicas manifestações de reativação pelo Trypanosoma cruzi em receptora de rim por transplante. Rev Soc Bras Med Trop 1997;30:61-3.

7. Pittella J.E.H. Central Nervous system involvement in Chagas' disease. An updating. Rev Inst Med Trop São Paulo 1993; 35:111-6.

8. Sartori A.M.C., Lopes M.H., Caramelli B., et al. Simultaneous occurrence of acute myocarditis and reactivated Chagas' disease in a patient with AIDS. Clin Infect Dis 1995;21:1297-9.

9. Rocha A., Ferreira M.S., Nishioka S.A., et al. Trypanosoma cruzi meningoencephalitis and myocarditis in a patient with acquired immunodeficiency syndrome. Rev Inst Med Trop São Paulo 1993;35:205-8.

10. Ferreira M.S., Nishioka S.A., Silvestre M.T., et al. Reactivation of Chagas' disease in patients with AIDS: report of three new cases and review of the literature. Clin Infect Dis 1997;25:1397-400.

11. Sartori, A.M.C., Sotto M.N., Braz L.M.A., et al. Reactivation of Chagas' disease manifested by skin lesions in a patient with AIDS. Trans R Soc Trop Med Hyg 1999;93:631-2.

12. Iliovich E., López R., Kum M. Uzandizaga G. Peritonitis espontánea en un enfermo de SIDA. Medicina (B Aires) 1998;58:507-8.

13. Lages-Silva E., Ramirez L.E., Silva-Vergara M.L., Chiari E. Chagasic meningoencephalitis in a patient with acquired immunodeficiency syndrome: diagnosis, follow-up and genetic characterization of $T$. cruzi. Clin Infect Dis 2002;34:118-23.

14. Montero A., Cohen J.E., Martinez D.P., Giovannoni A.G. Tratamiento empírico anti-toxoplasma en SIDA y Chagas cerebral: relato de dos casos, revisión de la bibliografía y propuesta de un algoritmo. Medicina (B Aires) 1998;58:504-6.
15. Gallo P., Fabião Neto O.M., Suarez J.M.M., Borba R.P. Acute central nervous system infection by Trypanosoma cruzi and AIDS. Arq Neuropsiquiatr 1992;50:375-7.

16. Ferreira M.S., Nishioka A.S., Rocha A., et al. Acute fatal Trypanosoma cruzi meningoencephalitis in a human immunodeficiency virus - positive hemophiliac patient. Am J Trop Med Hyg 1991;45:723-7.

17. Rocha A., de Meneses A.C.O., Moreira A., et al. Pathology of patients with Chagas' disease and AIDS. Am J Trop Med Hyg 1994;50:261-8.

18. Labarca J., Acuña L., Saavedra H., et al. Enfermedad de Chagas en el sindrome de inmunodeficiencia adquirida. Casos clínicos. Rev Med Chil 1992;120:174-9.

19. Cohen J.E., Tsai E.C., Ginsberg H. J., Godes J. Pseudotumoral chagasic meningoencephalitis as the first manifestation of acquired immunodeficiency syndrome. Surg Neurol 1998;49:324-7.

20. Solari A., Saavedra H., Sepulveda C., et al. Successful treatment of Trypanosoma cruzi encephalitis in a patient with hemophilia and AIDS. Clin Infect Dis 1993; $16: 255-9$

21. Galhardo M.C.G., Martins I.A., Hasslocher-Moreno A., et al. Reativação da infecção por Trypanosoma cruzi em paciente com síndrome de imunodeficiência adquirida. Rev Soc Bras Med Trop 1999;32:291-4.

22. Sartori A.M.C., Shikanai-Yasuda M.A., Amato Neto V., Lopes M.H. Follow-up of 18 patients with human immunodeficiency virus infection and chronic Chagas' disease, with reactivation of Chagas' disease causing cardiac disease in three patients. Clin Infec Dis 1998; $26: 177-9$.

23. Karp C. L., Neva F.A. Tropical infectious diseases in Human Immunodeficiency virus-infected patients. Clin Infec Dis 1999;28:947-65.

24. Ferreira M.S. Infections by protozoa in immunocompromised hosts. Mem Inst Oswaldo Cruz 2000;95:159-62.

25. Braz L.M.A., Amato Neto V., Carignani F.L., Marchi C.R. Trypanosoma cruzi parasitemia observed in immunocompromised patients: the importance of the artificial xenodiagnosis. Rev Inst Med Trop São Paulo 2001;43:113-5.

26. Hoff R., Teixeira R.S., Carvalho J.S., Mott K.E. Trypanosoma cruzi in the cerebrospinal fluid during the acute stage of Chagas' disease. N Engl J Med 1978;298:604-6.

27. Lazo J., Meneses A.C.O., Rocha A., et al. Chagasic meningoencephalitis in the immunodeficient. Arq Neuropsiquiatr 1998;56:93-7.

28. Torrealba G., Acuña G., Tagle P., Tapia J., Huete I. Valor de la biopsia cerebral en pacientes com SIDA y lesiones expansivas cerebrales. Rev Med Chil 1990;118:1367-71. 
29. Lazo J.E., Meneses A.C.O., Rocha A., et al. Meningoencefalites toxoplásmica e chagásica em pacientes com infecção pelo vírus da imunodeficiência humana: diagnóstico diferencial anatomopatológico e tomográfico. Rev Soc Bras Med Trop 1998;31:163-71.

30. Nishioka S.A. Benznidazol na quimioprofilaxia primária da reativação de doença de Chagas em chagásicos crônicos em uso de corticosteróides em doses imunodepressoras: há evidência suficiente para a recomendação do seu uso? Rev Soc Bras Med Trop 2000;33:83-5. 